\title{
OS ALIMENTOS GRAVÍDICOS FRENTE AO PRINCÍPIO DA PRESUNÇÃO DE INOCÊNCIA
}

Antonio de Padua dos Santos

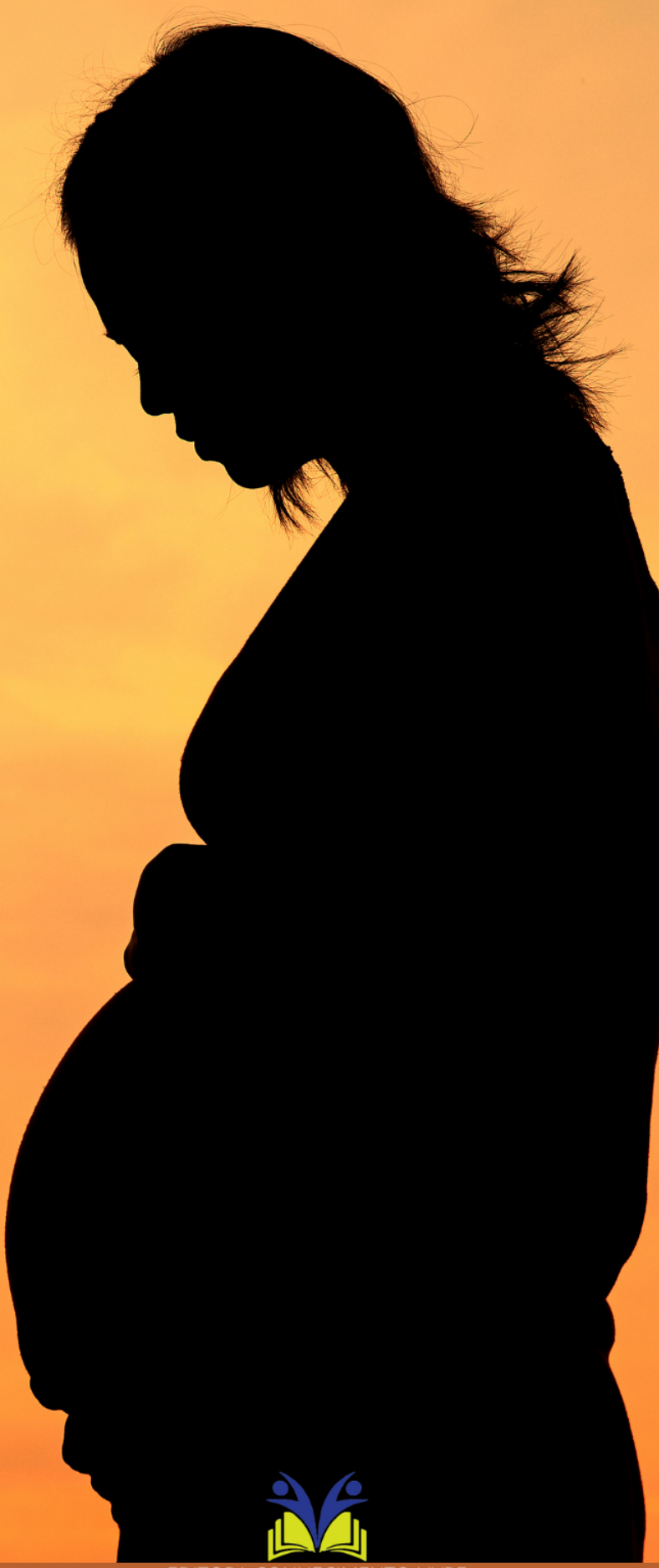


Antonio de Padua dos Santos

Os Alimentos Gravídicos Frente ao Princípio da Presunção de Inocência

$1^{\text {a }}$ ed.

Piracanjuba-GO

Editora Conhecimento Livre

Piracanjuba-GO 
$1^{\mathrm{a}} \mathrm{ed}$

\section{Dados Internacionais de Catalogação na Publicação (CIP)}

Santos, Antonio de Padua dos

S237O Os Alimentos Gravídicos Frente ao Princípio da Presunção de Inocência

/ Antonio de Padua dos Santos. - Piracanjuba-GO

Editora Conhecimento Livre, 2021

$41 \mathrm{f} .:$ il

DOI: $10.37423 / 2021 . e d c l 228$

ISBN: 978-65-89145-78-3

Modo de acesso: World Wide Web

Incluir Bibliografia

1. direito 2. civil 3. alimentos 4. dignidade 5. nascituro I. Santos, Antonio de Padua dos II. Título

CDU: 340

https://doi.org/10.37423/2021.edc1228

O conteúdo dos artigos e sua correção ortográfica são de responsabilidade exclusiva dos seus respectivos autores. 


\section{EDITORA CONHECIMENTO LIVRE}

\section{Corpo Editorial}

Dr. João Luís Ribeiro Ulhôa

Dra. Eyde Cristianne Saraiva-Bonatto

MSc. Anderson Reis de Sousa

$\underline{\text { MSc. Frederico Celestino Barbosa }}$

MSc. Carlos Eduardo de Oliveira Gontijo

MSc. Plínio Ferreira Pires

Editora Conhecimento Livre

Piracanjuba-GO 
Os Alimentos Gravídicos Frente ao Princípio da Presunção de Inocência

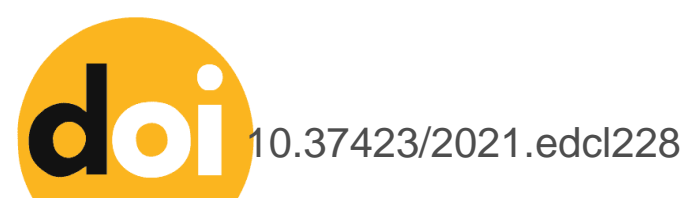

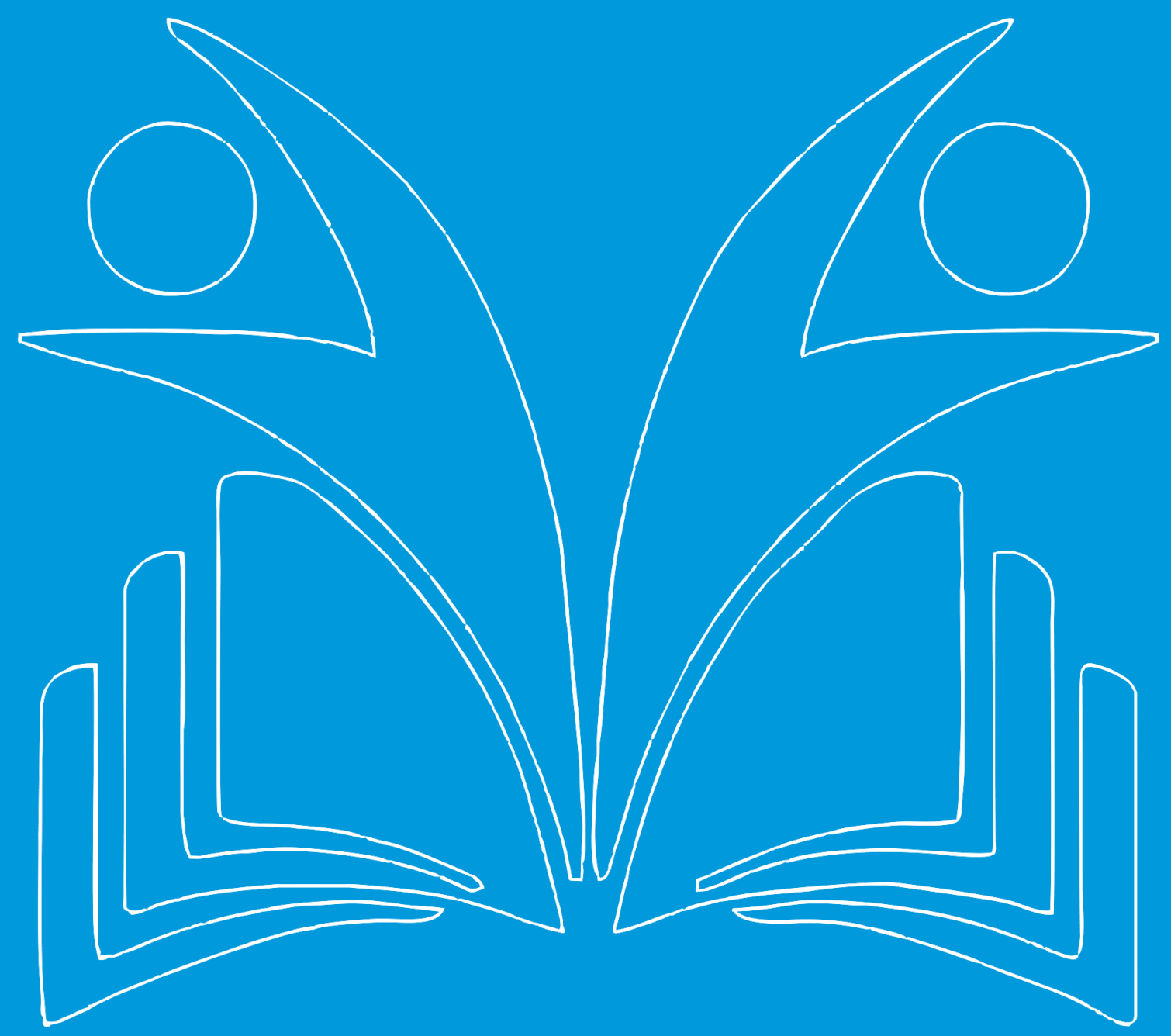


A Isabedeu, homem que se tornou o tronco de toda a família Marques. À dona Agripina que não desistiu de lutar pelos filhos.

E a você, Luiz Marques dos Santos,

Minha eterna gratidão. 


\section{AGRADECIMENTOS}

Escrever um livro em tão pouco tempo só seria possível com a ajuda de pessoas especiais.

Agradeço ao apoio incondicional da minha família, em especial à Maria da Paz, ao Matheus e à

Gabriella, Raquel e Marco Aurélio, que abriram mão de um tempo importante e escasso - que a princípio seria dedicado a eles - para que eu me dedicasse a esta obra.

Agradeço a oportunidade de entrar nesse projeto, que me foi oferecido pelo professor e pós-doutor Paulo Sergio. Sem ele, nada disso teria sido possível.

Não posso deixar de mencionar pessoas próximas a mim, parentes, que me inspiraram com sua coragem, para que eu pudesse levar este trabalho até o resultado.

Por fim, agradeço aos colegas que me apoiaram e têm me dado muito incentivo em todos os momentos. Que este livro seja um sucesso para todos nós. 


\section{PREFÁCIO}

Esta obra procurou trazer para reflexão esclarecimenos sobre um tema muito importante para toda a sociedade, que é a questão dos alimentos gravídicos, seus aspectos legais e jurisprudenciais com base na Constituição Federal de 1988, á luz do Direito moderno. O conteúdo é apresentado em capítulos que prouram repassar uma abordagem sobre a família desde os primórdios das civilizações, trazendo para reflexão a visão da doutrina, acerca desse importante instituto que se encontra inserido no ramo do Direito Civil, que é o direito das famílias. Apesar do alimento ser uma necessidade básica de todo ser vivo e um direito fundamental da pessoa, os alimentos gravídicos necessitaram ser regulamentados, para que fosse disciplinada a sua forma de exercer. O presente trabalho procura demonstrar à luz da legislação e jurisprudência vigentes os possíveis efeitos da concessão de alimentos à gestante, confrontando com o princípio constitucional da presunção de inocência. No que concerne ao princípio da presunção de inocência, é importante o entendimento sobre o significado deste, no âmbito das garantias fundamentais, quanto ao cerceamento da liberdade do suposto pai, como sendo, de um lado, a luta pela liberdade individual, ou seja, a briga entre o Estado e o afrontamento ao indivíduo, em detrimento da própria afirmação do Estado em favor do futuro cidadão: o nascituro, visando a garantia dos direitos deste, sobretudo a dignidade da pessoa humana.

Antonio de Pádua dos Santos 


\section{Sumário}

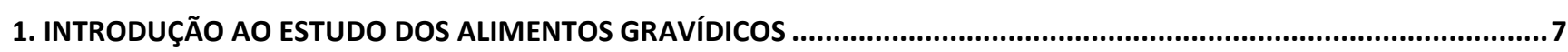

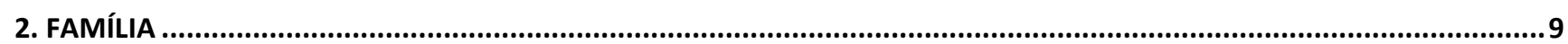

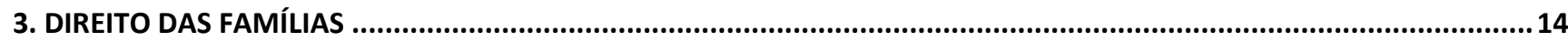

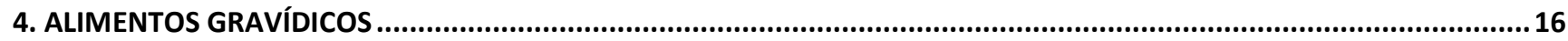

5. OS ALIMENTOS GRAVÍDICOS FRENTE AO PRINCÍPIO DA PRESUNÇÃO DE INOCÊNCIA ..............................................25

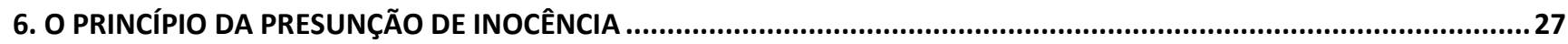

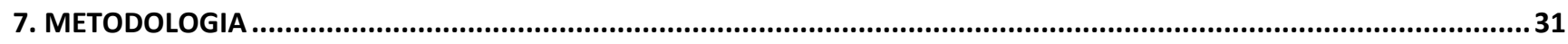

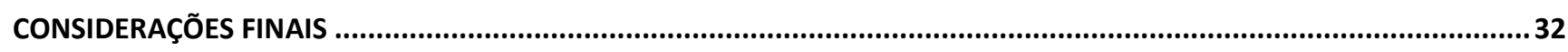

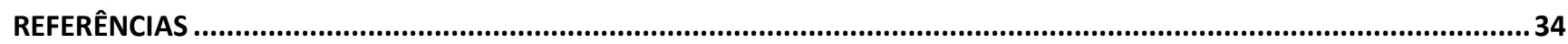

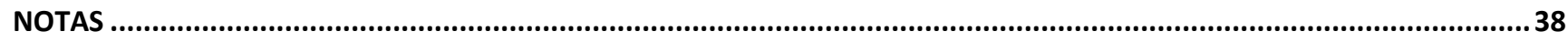




\section{INTRODUÇÃO AO ESTUDO DOS ALIMENTOS GRAVÍDICOS}

"O melhor homem é prudente no conselho e ousado nos atos"

\section{(Heródoto)}

Sobre a questão dos alimentos gravídicos, esta se apresenta de modo que em meio a uma imprescindibilidade da realização de uma ampla discussão no contexto do que diz respeito ao direito de família moderno. Algo que ainda havendo de contemplar toda uma atenção, para que assim, exista a possibilidade de prestar uma assistência através da jurisdição brasileira de forma tal que compatível tanto com a legislação aplicada no presente momento como quanto aos anseios da sociedade. $E$ isto ao chamar atenção, por exemplo, tanto para com a Lei de no $11.804 / 08$, como para com a garantia do direito aos alimentos necessários ao sustento do nascituro. Direito este, cujo comprometimento podese dizer como atribuição para sua efetivação pelo que diz respeito ao suposto pai enquanto obrigação de prestar uma colaboração assegurando alimentos conforme aqui de certa maneira, já preestabelecido, como também pelo reconhecimento do nascituro perante feitos em prol das prerrogativas que lhe cabem ser contempladas.

Deste modo, eis que existe por considerar uma sinalização para com o ímpeto por uma mudança no que concerne o paradigma do Direito de Família (BRASIL, 2008), com a intenção de promover meios de garantir o atendimento às despesas com alimentos gravídicos conforme predisposições estabelecidas para a efetivação da resolução em correspondência ao direito em foco.

Toda uma interpretação no que tange a temática adotada, e que para a realização da mesma, sobre a hipótese no instante aplicada: A possibilidade de uma melhoria que se julga necessária na proporção em que se possa correlacionar a realidade hoje sobre a concessão dos alimentos à mulher durante o período gestacional, em razão de providências estabelecidas através da Lei no $11.804 / 2008$, e do não afrontamento ao princípio da presunção da inocência.

Quanto às questões norteadoras: O que implica uma relação do Direito de Família com uma ênfase para a Lei $n$ ㅇ 11.804/2008, quando de um entendimento quanto à concessão dos alimentos gravídicos da mulher e quanto a uma veemência ao não desacato ao princípio da presunção da inocência conforme previsto através da Constituição Federal brasileira? e: De que forma vem sendo trabalhada tanto a legislação como a jurisprudência, diante do propósito relativo ao cumprimento da concessão de alimentos à gestante, na medida em que haja de se promover uma atuação considerando as possíveis repercussões em função do privilégio da mulher assim concebido? 
Já sobre os objetivos: Objetivo Geral: Identificar dados sobre a aplicação da legislação e da jurisprudência vigentes diante de uma referência a possíveis efeitos da concessão de alimentos à gestante, confrontando com o princípio constitucional da presunção de inocência. E isto se pode dizer de modo que com a determinação sempre quando da viabilidade de um paralelo comparativo acerca das diferenças existentes em um determinado contexto próprio da concessão de alimentos no cenário familiar, especialmente, após a promulgação da Lei $n^{\circ} 11.804 / 08$, dentre outras normatizações. Objetivos Específicos: Selecionar todo um contexto sob um direcionamento a respeito da concessão de alimentos e a situação desta em consonância com termos voltados para o processo de tal ação, ao ter em mente um entendimento conforme a estruturação da família e a conjuntura legal em relação a aspectos relacionados à mesma.; Interpretar sobre o arcabouço histórico da família e a concessão dos alimentos perante a sociedade e a legislação em torno de tal questão, na medida em que exista por se fazer uma referência a termos conforme encadeamento de ideias diante, que, portanto, da temática aqui retratada.; Redigir a respeito de aspectos inerentes à concessão dos alimentos em meio a circunstâncias no que tange aspectos vinculados ao termo gravídico e ao que remete uma relação para com termos jurídicos como também constitucionais em conformidade com a legislação e a jurisprudência em vigor.; e, Apresentar uma abordagem em relação à concessão dos alimentos com um entendimento em concomitância ao princípio da presunção de inocência, dentre outros aspectos norteadores, contudo um sentido maior eis que para tal princípio, como também para particularidades próprias da conjuntura da família, enquanto aspectos propícios à prerrogativa sobre a concessão abordada.

Acerca da justificativa empregada, eis que se fez por colocar em prática: A viabilidade de um estudo sobre o desígnio do Direito de Família no que concerne à aplicação de recursos legais voltados para a institucionalização dos alimentos gravídicos. E assim, ser possível contribuir com o cumprimento do direito no que confere uma menção aos alimentos da mulher gestante e o modo que deva ser aplicada a prerrogativa aqui referenciada.

Um estudo como previamente apresentado sobre alimentos gravídicos de uma maneira que tomando por base indícios tais, na proporção em que se tenha como meta privilegiar a importância da vida humana frente a um conflito com o que se refira ao princípio da presunção de inocência. A dignidade da pessoa humana também tendo sua magnitude enquanto privilégio da vida do nascituro, em razão do que seja visto como responsabilidade de um suposto pai em conceder alimentos, não se baseando somente em impressões no que concerne um discernimento relativo ao termo paternidade. 


\section{FAMÍLIA}

"Quando aprovamos boas ações, fazemo-las nossas de certo modo"

\section{(Thomas Fuller)}

Nos primórdios das civilizações, com o desaparecimento da família pagã, a família cristã guardou o caráter de unidade através do casamento, como culto, numa época em que a família já era considerada a célula básica da igreja, e a proteção do patrimônio, incumbia ao filho primogênito, bem como, mantê-lo unido, em prol da unidade religiosa familiar.

O casamento era obrigatório. Não tinha por fim o prazer; o seu objeto principal não estava na união de dois seres mutuamente simpatizantes um com o outro e querendo associarem-se para a felicidade e para as canseiras da vida. $O$ efeito do casamento, à face da religião e das leis, estaria na união de dois seres no mesmo culto doméstico, fazendo deles nascer um terceiro apto para continuador desse culto" (Coulanges, 1958, v. 1:69).

A partir dos últimos séculos, a ciência do direito demonstrou o caráter temporal do casamento, que passou a ser regulamentado pelo Estado, e a partir do século XIX o inseriu nas codificações como baluarte da família.

No direito Romano, a palavra "família" é aplicada em diversas acepções, entretanto, quando aplicada aos indivíduos, às vezes exprimia a reunião das pessoas colocadas sob o Poder pátrio ou o manus de um chefe único: "iure próprio familiam dicimus plures personas, quae sunt subunius potestate, aut natura aut iure subiectae. (L. 195, §2, D, de verborum significatione, 50, 16)". (MIRANDA, 2000, p.

203).

Diante do exposto, sobre família como então configurada, isto de modo que especialmente falando, a mesma compreende além de uma referência ao pai, à mãe e aos filhos também, e sob uma percepção geral, mostra-se de forma que compreendendo os parentes na sua totalidade (MIRANDA, 2000).

Quando pensamos em família, temos a noção de casamento, ou seja, união de pessoas de sexos diferentes, unidas pelo matrimônio. Para Venosa (2008,

p. 3), dentre os vários organismos sociais e jurídicos, o conceito de família, foi "o que mais se alterou no curso dos tempos".

No passado, a família era uma comunidade rural, integrada por todos os parentes, formando uma unidade de produção, com um amplo incentivo à procriação. Esta família pertencia a uma sociedade conservadora, e para merecer a aceitação social, dispunha de um perfil hierarquizador e patriarcal, necessitando do matrimônio. Assim, a família tratava-se de uma entidade patrimonializada, cuja força 
de trabalho era representada pelos seus membros, cujo crescimento ensejava melhores condições de sobrevivência a todos os membros da família.

Com a revolução industrial, o modelo familiar patriarcal não resistiu, devido a necessidade de se aumentar a mão de obra, principalmente, para as atividades terciárias. A revolução industrial também abriu as portas para o ingresso da mulher entrar no mercado de trabalho, deixando o homem de ser a única fonte de subsistência da família.

Em meio às mudanças trazidas pela revolução, a estrutura familiar sofreu diversas alterações, passando a ser uma família nuclear, ou seja, restrita ao casal e a sua prole, e com o fim da prevalência do seu caráter produtivo e reprodutivo, provocando uma migração desta família do campo para as cidades, vindo a conviver em espaços menores, o que levou a uma aproximação maior entre os seus membros, vindo a ser prestigiado o vínculo afetivo, que envolve seus integrantes.

Avançando no tempo, é fácil perceber que a valorização do afeto deixou de se limitar apenas ao momento da celebração do matrimônio, devendo perdurar por toda a relação. Com isso, cessado o afeto, está ruída a base de sustentação da sociedade familiar, ou seja, a dissolução do vínculo do casamento é o único modo de garantir a dignidade da pessoa. (FARIAS, 2007)

Entretanto, apesar de tantas mudanças, pensar em família traz a mente o modelo convencional, um homem e uma mulher, unidos pelo casamento e cercados pelos filhos. Mas essa realidade já não é a mesma cantada na música, a exemplo da Banda Titãs, na música "Família". ${ }^{i}$

Família Família, família

Papai, mamãe, titia Família, família

Almoça junto todo dia

Nunca perde essa mania

Mas quando a filha quer fugir de casa precisa descolar um ganha pão

Filha de família se não casa

Papai, mamãe não dão nenhum tostão

Família ê

Família ah Família

Família é Família ah

Família

Família, família

Vovô, vovó, sobrinha Família, família janta junto todo dia

Nunca perde essa mania 


\section{$[\ldots]$}

Quanto ao conceito de família, segundo o posicionamento de Fiúza (2008, p. 939), sob uma ampla percepção, pode-se considerar família como sendo:

Uma reunião de pessoas descendentes de um tronco ancestral comum, incluídas aí também as pessoas ligadas pelo casamento ou pela união estável, juntamente com seus parentes sucessíveis, ainda que não descendentes.

No entanto, conforme mesma autoria, em meio a um sentido mais restrito, é possível interpretar família sob o ponto de vista de que seja: "uma reunião de pai, mãe e filhos, ou apenas um dos pais com seus filhos". (FIÚZA, 2008, p. 939)

E isto ainda que exista a possibilidade de entender família dentre a alterações diante do conceito da mesma, quando dentre aos organismos sociais e jurídicos, ter sido o que mais veio por vivenciar mudanças durante trajetória da humanidade (VENOSA, 2008).

Alterações estas no que vale uma ressalva para a estrutura familiar sob uma determinada intervenção na organização dos vínculos interpessoais dentro do contexto em que se fez por constituir a família (DIAS, 2017).

Intervenção que ao considerar uma interferência jurídica, isto dentre a uma evolução do que implica chamar atenção para com do direito das famílias dentre a uma dinamicidade de fatos na medida em que levasse em conta, dentre outros pontos, a proteção da entidade família. E isto ainda que por fazer uma referência a um processo de readaptação no que implica uma menção à família a partir de uma jurisdição voltada para sua estruturação enquanto argumentação com vistas a atuar que, portanto, pela organização familiar. Idem

Uma evolução quando de uma alusão à adoção de dispositivos legais ao se referir, por exemplo, à Constituição Federal de 1988 em que se fez interferir no conceito de família conforme Dias (2017). E isto ainda que também pelo que tange norteios enquanto princípios adotados na aplicabilidade do Direito na forma que a família vem se compondo.

Por princípios, Barroso (1998, p.141apud LIMA,2002) os percebeu de modo a considerar dentre a uma interpretação como a seguir colocada: “[...] o ponto departida do intérprete há que ser sempre os princípios constitucionais, que são o conjunto de normas que espelham a ideologia da Constituição, seus postulados básicos e seus fins."

Sobre princípios, estes ainda que também se apresentam de modo que identificados como sendo normas de natureza jurídica em meio a posição destas em uma conjuntura referente a um elevado 
estágio de generalidade e à forma de serem interpretados enquanto preceitos melhoramento, como no tocante, aqui, à formação da família (DIAS, 2015).

E assim, pois, uma constitucionalização existe por se chamar atenção para a efetividade do Direito Civil, e de maneira que especificamente falando, no que cabe uma associação com Direito de Família, em conformidade com o vínculo entre o texto constitucional e temas importantes identificados no âmbito jurídico aqui relacionado (DIAS, 2017).

O vínculo afetivo sempre existiu, através do acasalamento entre os seres vivos, mas isto não se trata de uma prerrogativa apenas da espécie humana, não só em decorrência do instinto da perpetuação da espécie, seja pela verdadeira aversão que todos têm à solidão.

E assim, parece que as pessoas somente são felizes quando tem alguém para amar. Sendo a vida aos pares, trata-se de um agrupamento informal, de formação espontaneamente no meio social, é no direito que se dá a sua estruturação, no dizer de Hironaka (1999, p. 8):

Não importa a posição que o indivíduo ocupe na família, ou qual a espécie de grupamento familiar a que pertença - o importante é pertencer ao seu âmago, é estar naquele idealizado lugar onde é possível integrar sentimentos, esperanças, valores e se sentir, por isso, a caminho da realização de seu projeto de felicidade.

A família, por ser uma construção cultural, no dizer de Dias (2011), dispõe de uma estruturação psíquica, na qual todos ocupam um lugar, possuindo uma função, ou seja, o lugar do pai, no centro, ao lado da mãe, o lugar dos filhos, sem, necessariamente, estarem ligados biologicamente.

É sabido que a própria organização da sociedade se dá em torno da família da estrutura familiar, como o LAR: Lugar de Afeto e Respeito. A saber, em determinado momento histórico o Estado, por seu poder intervencionista instituiu o casamento como regra de conduta (DIAS, 2011).

Assim, por uma convenção social foi possível organizar os vínculos interpessoais, a exemplo da família formal, que por uma intervenção demográfica, onde somente se permitia a multiplicação da população, através da família, sendo essa a forma encontrada para o Estado impor limites ao homem, se desejante que, na busca de prazer, tende a fazer do outro um objeto. É por isso que o desenvolvimento da civilização impõe à civilização impõe restrições à total liberdade, e a lei jurídica exige que ninguém fuja dessas restrições. (PEREIRA, 2005)

O conceito de família, esposado pela doutrina majoritária, longe de ser homogênea, trata a família como uma "instituição", ainda que também a interpretando a família como uma coletividade humana subordinada à autoridade e condutas sociais. Nesse sentido, família é uma união associativa de 
pessoas, sendo uma instituição da qual se vale a sociedade para regular a procriação e educação dos filhos. (VENOSA, 2016)

Nos dias de hoje, todos estamos acostumados com famílias que afastam do perfil tradicional. Assim, a convivência com diversos tipos de grupos familiares, a exemplo das famílias recompostas, monoparentais, homoafetivas permite-nos reconhecer que ela se pluralizou, daí percebe-se a necessidade de flexionar igualmente o termo que a identifica, com todas as suas conformações.

Segundo Perrot (1993), despontam novos modelos de famílias, mais igualitárias nas relações de sexo e idade, mais flexíveis em suas temporalidades e em seus componentes, menos sujeitas a regra e mais ao desejo.

Na atualidade, dada a vastidão de mudanças das estruturas políticas, econômicas e sociais trouxe reflexos nas relações jurídico-familiares, que elevaram a proteção da pessoa humana, influenciada pelos ideais de pluralismo, solidarismo, democracia, igualdade e humanismo, com isso, a família adquiriu função instrumental para melhor realizar seus interesses afetivos e existenciais de seus membros.

Em conformidade com o exposto logo acima, pode-se dizer que nesse contexto de grande mobilidade das configurações dos arranjos familiares, novas formas de convívio vêm sendo improvisadas em torna da necessidade - que não se alterou - de criar os filhos, frutos de uniões amorosas temporárias, que não se conseguem que se obriguem que se eternizar, nem por nenhuma das leis, ou pela vontade de Deus ou dos homens.

A família moderna difere das formas antigas de família no que concerne a suas finalidades, composição e papel de pais e mães, além do mais, já que era formada por pais e filhos, não sofrendo tanta alteração com a sociedade urbana.

Entretanto, no contexto do mundo globalizado, apesar da família continuar a ser essencial para a própria existência da sociedade e do Estado, houve uma completa reformulação do seu conceito (GAMA, 1998).

Atualmente, as responsabilidades dos pais pelas atividades dos filhos passaram a ser preenchidas pela escola e outras instituições de educação, esportes e recreação, ou seja, a educação dos filhos cabe ao Estado, bem como as funções de assistência à criança, adolescente, idosos e necessitados ou a instituições privadas por ele supervisionadas, e a religião deixou de ser ministrada em casa, e têm sido assumidas pelo Estado. 


\section{DIREITO DAS FAMÍLIAS}

"Uma adolescência libidinosa e desregrada entrega à velhice um corpo cansado"

\section{(Cícero)}

Sobre o Direito de Família, de acordo com Tartuce (2017), o ramo do Direito Civil que se apresenta de modo ter conteúdo toda uma questão no que envolve dentre demais institutos jurídicos, o que corresponde um sentido para com o termo alimentos. Ainda que, por demais, possa-se afirmar que em todos os ramos do Direito

Civil, especialmente com o Direito de Família, seja fundamental que o Estado, através do Poder Judiciário, proporcione segurança aos seus cidadãos partindo de decisões proferidas pelo mesmo. E ainda que neste particular, assim uma referência se faça à segurança conforme, que, portanto, aos preceitos, caracteristicamente, jurídicos, que dentre eles, a segurança jurídica.

Por segurança jurídica, segundo Torres (2005, p. 74), "Segurança jurídica é certeza e garantia de direitos. [...] A segurança jurídica significa, sobretudo segurança dos direitos fundamentais. ". E ainda que também, Acerca da segurança jurídica, para Penariol (2012), eis a afirmação de que a mesma faça se de modo que imprescindível à devida subsistência do Estado Democrático de Direito ii sob uma perspectiva onde cabe chamar atenção para o princípio da segurança jurídica. Quanto ao princípio aqui referenciado, neste sentido, havendo o atribuir a função de "de assegurar a todos os cidadãos que as leis serão cumpridas, inclusive pelo próprio Estado." (PENARIOL, 2012, p. 3).

Algo, que por este anglo, intervindo-se pela efetivação da justiça social, ei um outro entendimento, ao afirmar que: "A tarefa fundamental do Estado de Direito consiste em superar as desigualdades e instaurar em regime democrático que realize a justiça social”. (SILVA, 2002, p. 257)

Uma superação que para tanto se acredita ser relevante levar em conta outra percepção ao ter em vista neste momento o ativismo judicial e a protagonização de decisões de suma importância no que diz respeito, por exemplo, ao estabelecimento do direito aos alimentos gravídicos. Ativismo judicial este que exprime a

[...] liberdade consciente e prudente, com respeito aos princípios constitucionais, dentre eles o da segurança jurídica, de criação dos tribunais pautada na interpretação legal e com o fulcro supremo na efetivação de direitos contidos na Constituição [...]. (SOUZA JUNIOR; MEYER-PFLUG, 2013, p. 467490).

E ainda que por este feito no que se refira o ativismo judicial, Ramos (2010, p. 70) promoveu a seguinte contextualização: 
[...] o exercício da função jurisdicional para além dos limites impostos pelo próprio ordenamento que incumbe, institucionalmente, ao Poder Judiciário, atuar resolvendo litígios de feições subjetivas (conflitos de interesses) e controvérsias de natureza objetiva (conflitos normativos).

Uma atuação diante da previsão quanto ações previstas através da Lei de no $11.804 / 2008$, e que por este prisma revela-se como medida legal a concessão de alimentos à mulher gestante, tratando-se de uma norma especial dentro do contexto da legislação como atualmente vem sendo aplicada, tanto constitucional como jurídica (BRASIL, 2008).

Uma concessão ainda que em torno de uma comprovação legal que veio por surgir, com fins de garantir a efetividade deste paradigma, imperando a ruptura de uma sociedade alicerçada no pátrio poder, para que fossem permitido avanços quanto à natureza indenizatória dos alimentos e condição jurídica do nascituro iii. Algo, que a partir do mesmo havendo possibilidade de perceber os alimentos como um direito social, conforme preceitua o art. 6ำ, da Constituição Federal brasileira (BRASIL, 2015), havendo necessidade de uma análise atenuante acerca dos alimentos gravídicos e circunstâncias. $\mathrm{E}$ isto ainda que também conforme explícito sob a presença do Direito de Família intervindo pela jurisdição voltada para tal questão, ou seja, para como o que interceda pela garantia do direito à prerrogativa no que tange aos alimentos gravídicos.

Para a intervenção do Direito de Família, isto diante da aplicabilidade do ramo do Direito Civil como assim mencionado na medida em que se leve em conta princípios, e isto de maneira que se fazendo por conduzir o cumprimento relativo à concessão dos alimentos gravídicos.

Deste modo, destaca-se como relevante contemplar os princípios diante das pretensões por parte da sociedade brasileira como um todo, incluindo aqui além de cada pessoa que a constitui, o ordenamento jurídico brasileiro também tendo como suporte dentre outros, tais regras. $E$ isto na medida em que para tanto, tais fundamentos se mostram em meio a circunstâncias, e isto de modo a terem que: "[...] conquistar o status de norma jurídica, superando a crença de que teriam uma dimensão puramente axiológica, ética, sem eficácia jurídica ou aplicabilidade direta e imediata." (BARROSO; BARCELLOS, 2003, p. 147-148)

E isto sob uma esfera no que se faça por adequar-se a princípios constitucionais em meio a uma referência a pontos relevantes dentro do contexto que envolve o Direito de Família e a concessão dos alimentos gravídicos, por exemplo, dentro de um processo evolutivo vivenciado pela sociedade. 
Processo este relativo à evolução de fatos em função do que se refira ao instituído através da Constituição Federal de modo que favorecendo a valorização do indivíduo como sujeito e não como objeto de direito.

Com base no exposto logo acima, por conseguinte, ao reconhecer a força legal que cada pessoa trouxe em sua essência, como também a igualdade entre este ser humano dentre os demais em face de uma alusão aos direitos imprescindíveis a tais questões. Algo que em torno do Estado Democrático de Direito, eis, um sentido para com a dignidade da pessoa humana, conferindo à mesma, umvalor supremo segundo Cocurutto (2008).

E assim, eis a afirmação de que a dignidade humana desta maneira se dispõe a atrair o conteúdo de todos os direitos fundamentais do homem, desde o direito à vida, intervendo pela reunião de dos direitos aqui configurados (COCURUTTO, 2008).

\section{ALIMENTOS GRAVÍDICOS}

"Esquece o benefício que concedes, mas lembra-te sempre do que recebes"

\section{(Quílon)}

É possível afirmar que o primeiro direito fundamental do ser humano é o de sobreviver. Entretanto, nos tempos da história da Grécia e de Roma, na antiguidade, foi constatado que persistiu para o homem, nas crenças sobre a alma e sobre a morte, contado por Ovídio e Virgílio, que em cerimônia em que era levado alimento pela família, aos seus mortos, uma vez que esses passavam a seres sagrados. iv

No Brasil, os alimentos mostram-se regulados dentre a uma diversidade de textos legais, mas é no Código Civil é que se encontra a maioria de suas regras. Nos arts. 1.694 a 1.710 há diversas disposições sobre alimentos enquanto direito de família. Alguns outros diplomas legais que também tratam disso são a Constituição da República Federativa do Brasil (CF/88), o Código de Processo Civil (CPC/2015) e as Leis nos $5.478 / 68,6.515 / 77,8.560 / 92$ e 11.804/08.

E deste modo, percebe-se que desde os primórdios da nossa civilização, pode-se afirmar que o primeiro direito fundamental do ser humano é o direito à sobrevivência (DIAS, 2009). Repousa nessa premissa, compromisso maior do Estado, primeiramente, na garantia da vida das pessoas, com a prestação de alimentos aos seus cidadãos, na pessoa de cada ente que integra a família.

E isto no que vale fazer por mencionar todo um processo onde há a viabilidade de constatar meios legais à garantia do direito a alimentos em meio à institucionalização de dispositivos normatizadores. 
Dentre ao propósito em tecer sobre o conceito de alimentos gravídicos, inicialmente no que concerne uma compreensão sobre o termo alimentos, eis uma análise que partindo da mesma seja possível entender tal expressão do seguinte modo:

A expressão alimentos vem adquirindo dimensão cada vez mais abrangente. Engloba tudo que é necessário para alguém viver com dignidade, dispondo o juiz de poder discricionário para quantificar o seu valor. (DIAS, 2011, p. 515)

Os alimentos gravídicos apresentam-se de forma que em função seja em decorrência tanto de parentesco, como de casamento, no que se refira à união estável ou até mesmo de uma relação à base de namoro, e que para tanto requisitos se deva considerar. Requisitos estes como no tocante a um sentido para com meios que possam comprovar a real efetivação da concessão dos alimentos como então aqui em estudo, no que se faz por reportar-se a uma compreensível presença de indícios de paternidade v. (SILVA, 2013)

De acordo com a respectiva Lei de Alimentos Gravídicos, a Lei no 11.804/08, sabe-se que a mesma estabelece através do seu Art. $2^{\circ}$, e Parágrafo único em pertinência ao mesmo, o seguinte entendimento:

Art. 2 . Os alimentos de que trata esta Lei compreenderão os valores suficientes para cobrir as despesas adicionais do período de gravidez e que sejam dela decorrentes, da concepção ao parto, inclusive os referentes a alimentação especial, assistência médica e psicológica, exames complementares, internações, parto, medicamentos e demais prescrições preventivas e terapêuticas indispensáveis, a juízo do médico, além de outras que o juiz considere pertinentes.

Parágrafo único. Os alimentos de que trata este artigo referem-se à parte das despesas que deverá ser custeada pelo futuro pai, considerando-se a contribuição que também deverá ser dada pela mulher grávida, na proporção dos recursos de ambos. (BRASIL, 2008, p. 1)

$E$ isto ainda que no escopo de um estudo referente aos alimentos em meio a uma relação com o período da gestação da mulher, provisão esta diante de prestações para que haja possibilidade de satisfazer as necessidades vitais de quem não pode provê-las por si só no sentido como então expresso. Necessidades, tais, que devem compreender aquelas que sob um determinado ponto de vista, suficientes para cobrir todos os gastos com a alimentação em meio a uma concretude em relação às mulheres no período de gestação. Estas enquanto dignas de alimentos, que quando por si mesmas, está a se apresentar como pessoas incapazes de se cuidar, não conseguindo, pois, providenciar os recursos imprescindíveis à sua subsistência (FERST, 2013). 
Ainda que assim, sobre alimentos gravídicos, pode-se considerar como um reflexo do modo como a lei regula as relações familiares. Na tentativa de melhor compreender esse desiderato, em um primeiro momento, o homem deteve o poder familiar. Depois, em um segundo momento, o homem passou a exercer tal poder familiar, ou seja, antes ele era o "cabeça" do casal, o chefe da sociedade conjugal. Assim, era dele a obrigação de prover o sustento da família, o que se convertia em obrigação alimentar.

Em função da afirmação como então anteriormente colocada, supõe-se ser pertinente considerar outro conceito de alimentos quando do posicionamento de Venosa (2012), que assevera sobre alimentos de um modo tal que sob uma interpretação conforme certa determinação jurídica.

Desta maneira ao se fazer uma referência aos alimentos gravídicos e a garantia do alcance aos mesmos, a princípio no tocante a um sentido para com a Constituição Federal brasileira, art. 6ำ, e sua posição diante de tal questão, eis a garantia de que estes alimentos tem seu conhecimento entre os direitos sociais. Algo que regula como dever a ser cumprido pelo Estado o fornecimento de uma especial proteção à família, conforme norteia o art. 226 da legislação como anteriormente citada. (BRASIL, 2015)

Quanto à Lei no 11.804/2008, esta instituiu os denominados alimentos gravídicos, e, segundo o art. 1으 da referida norma jurídica, eis a constatação de que o mesmo "disciplina o direito de alimentos da mulher gestante e a forma como será exercido". Em vista disso, pode-se afirmar que apenas à mulher grávida atribui-se a viabilidade de ser digna no que diz respeito à aplicação dessa lei a seu favor. Todavia, caso a criança já tenha nascido, faz-se uso da Lei no 5.478/68, que dispõe acerca da ação de alimentos e concede outras providências.

Com base no exposto logo acima, haja de se considerar certa diferença entre alimentos gravídicos e alimentos no que corresponde o nascituro, porém conforme imposição legal é imprescindível afirmar que as obrigações atribuídas têm sua fundamentação antes mesmo do nascimento do filho (DIAS, 2017).

Um respaldo no que tange um discernimento que á respeito do mesmo isto de modo a levar em conta os alimentos gravídicos e sua concessão determinada sob a presença dos preceitos legais $(O R O, 2011)$. E que, pois, se diga à vista disso, eis de ser viável convencer o juiz diante do que se refira à "existência de indícios de paternidade" (FREITAS, 2009, p. 21). 
Desta maneira, ainda que no que se refere ao art. 60 e seu parágrafo único também da Lei no 11.804/2008, a tal artigo acrescenta algo em consonância com um sentido em relação a seguinte expressão:

Art. 6o Convencido da existência de indícios da paternidade, o juiz fixará alimentos gravídicos que perdurarão até o nascimento da criança, sopesando as necessidades da parte autora e as possibilidades da parte ré.

Parágrafo único. Após o nascimento com vida, os alimentos gravídicos ficam convertidos em pensão alimentícia em favor do menor até que uma das partes solicite a sua revisão.

Por fim, ainda que nos termos do art. 60, o juiz estabilizará alimentos gravídicos que virão a persistir até o nascimento da criança, ponderando determinado binômio. Expressão esta, e que, portanto, sobre o termo binômio, em que de um lado encontram-se além das necessidades, da utilidade também no que tange um sentido para com autora da ação impetrada e, de outro, as possibilidades por parte do indiciado. (SILVA, 2013)

A concessão dos alimentos gravídicos encontra-se fundamentada através da Constituição Federal em torno de termos que tanto em razão de princípios desta legislação, que dentre eles, o Princípio da Solidariedade, manifestando-se através do mesmo a procedência da obrigação alimentar. E sobre esta fonte no que possa se identificar como sendo os laços de parentalidade que ligam as pessoas constituintes de uma família. Alimentos como aqui em estudo, que ainda ser possível dizer que tem sua origem interpretada processando-se como princípio da preservação da dignidade da pessoa humana vi, inscrito no art. 1ํ, inciso III, também da Constituição Federal de 1988. (ORO, 2011)

Nessa mesma direção, Silvio de Salvo Venosa vii, ao esposar seu entendimento, dispõe que o interesse em foco é a proteção da vida, de maneira efetiva e concreta, vida esta que apenas será completa se houver uma garantia ao mínimo existencial necessário, respeitando os princípios da dignidade da pessoa humana e ao princípio da solidariedade familiar:

Em linha fundamental, quem não pode prover a própria subsistência nem por isso deve ser relegado ao infortúnio. A pouca idade, a velhice, a doença, a falta de trabalho ou outra incapacidade pode colocar a pessoa em estado de necessidade alimentar. A sociedade deve prestar-Ihe auxílio. O Estado designa em primeiro lugar os parentes para fazê-lo, aliviando em parte seu encargo social. Os parentes podem exigir uns dos outros os alimentos e os cônjuges devem-se mútua assistência. A mulher e o esposo, não sendo parentes ou afins, devem-se alimentos com fundamento no vínculo conjugal. Também os companheiros em união estável estão na mesma situação atualmente. Daí decorre, igualmente, o interesse público em matéria de alimentos. Como vemos, a obrigação alimentar interessa ao Estado, à sociedade e à família. 
Sob outro prisma, existe um interesse público do Estado, para que a obrigação alimentar do devedor seja efetivada, e isto de forma que consolidado no decorrer da prisão do devedor, conforme dispõe o art. 5ำ, inciso LXVII também expresso através da Constituição Federal. Entretanto, essa prisão, apenas baseada em "indícios de paternidade", torna-se alvo de discussão entre os agentes do direito. E isto porque o referido dispositivo pode depreciar a presunção da inocência. Conclusão esta que como tal, expressa por intermédio do art. 5ำ, inciso LXII Constituição ainda aqui em fito. (BRASIL, 2015)

Ainda que segundo Cahali (2012, p. 347-348), acredita-se que haja necessidade de ponderar uma atenção maior para com uma menção à existência dos indícios de paternidade relacionados aos alimentos gravídicos, na medida em que se considere a seguinte questão:

Embora o legislador deixe transparecer certa liberalidade, ao referir que bastará para a fixação de alimentos gravídicos que esteja o juiz convencido da "existência de indícios da paternidade" (art. 6)), recomenda a prudência que tais indícios tenham alguma consistência, sejam seguros e veementes, especialmente diante do fato de a contribuição prestada pela parte ré ser considerada não repetível ou reembolsável. Seria leviandade pretender que o juiz deva se satisfazer com uma cognição superficial, embora se afirme não ser exigível prova pré-constituída da obrigação alimentar.

Daí decidir-se que, não havendo indícios de paternidade, tampouco comprovação do nexo causal entre gravidez e o ato sexual entre as partes, não se mostra viável a condenação do suposto pai a alimentos provisórios; caso contrário, pode vir este a sofrer danos irreparáveis, quando na ação principal não restar comprovado o grau de parentesco, em razão da irrepetibilidade das prestações alimentícias.

A doutrina atual intervém na concessão dos alimentos gravídicos defendendo que a sistemática imposta pela legislação acaba por permitir a tenacidade dos alimentos sob o veredito do julgador, já que este, o árbitro, se fundamentará em indícios que forem apresentados pela gestante pleiteante. Impressões que jamais conduzirão a um alto grau de credibilidade da paternidade. (BERALDO, 2017). Indícios enquanto provas possíveis de ser consideradas no deferimento da ação pela garantia do direito aos alimentos gravídicos, e isto diante de pontos até mesmo já identificados segundo o Agravo de Instrumento como então posteriormente apresentado:

\section{AGRAVO DE INSTRUMENTO. ALIMENTOS GRAVÍDICOS. PROVAS DA}

PATERNIDADE. POSSIBILIDADE. É bem de ver que a situação posta ao amparo da lei que garante os alimentos gravídicos, por si só, já traz circunstâncias de difícil comprovação. Difícil para a mãe, de plano, mostrar que tem um bom direito. Mostrar que o filho que ela carrega é do homem que está sendo demandado. É de rigor que o juízo corra algum risco quando se está em sede de provimento liminar. Por isso, em casos nos quais se pedem alimentos gravídicos, algumas regras que norteiam a fixação de alimentos devem ser analisadas com um tanto de parcimônia. É necessário flexibilizar-se certas 
exigências, as quais seriam mais rígidas em casos de alimentos de pessoa já nascida. Não se pode exigir que a mãe, de plano, comprove a paternidade de uma criança que está com poucos meses de gestação. Por outro lado, não há como negar a necessidade da mãe de manter acompanhamento médico da criança, fazer exame pré-natal, e outros procedimentos que visam ao bom desenvolvimento do filho e que demandam certos gastos. Por isso, no impasse entre a dúvida pelo suposto pai e a necessidade da mãe e do filho, o primeiro deve ser superado em favor do segundo. É mais razoável reconhecer contra o alegado pai um "dever provisório" e Ihe impor uma obrigação também provisória, com vistas à garantia de um melhor desenvolvimento do filho, do que o contrário. Nesse contexto, apesar da fragilidade da prova acerca da paternidade, é cabível a fixação dos alimentos provisórios. Por maioria, deram parcial provimento. Vencido o relator. (TRIBUNAL DE JUSTIÇA DO RIO GRANDE DO SUL.

Agravo de Instrumento 70047396924 Al. Oitava Câmara Cível, Tribunal de Justiça do Rio Grande do Sul. Relator: Rui Portanova. Julgado em 09/05/2012. Oitava Câmara Cível, Tribunal de Justiça do Rio Grande do Sul, 2012.). Julgado em 09 mai. 2012.

E isto ainda que se entenda ser interessante considerar os indícios enquanto meios de comprovação para a concessão dos alimentos gravídicos, e isto posto a compreensão de que sem uma fundamentação concreta, inviável se torne a prerrogativa como aqui circunstanciada.

Conforme o exposto como anteriormente colocado, algo quando de supõe-se de ser relevante considerar outro Agravo de Instrumento:

J-RS - Agravo de Instrumento Al 70074250002 RS (TJ-RS) Data de Publicação: 26/10/2017

\section{Ementa: AÇÃO DE ALIMENTOS GRAVÍDICOS. ALIMENTOS}

PROVISÓRIOS. A Lei n. 11.804/2008 regulamenta o direito de alimentos à gestante. Contudo, embora possível o deferimento liminar de alimentos provisórios, em se tratando de ação de alimentos gravídicos, imperioso que a demanda esteja instruída com elementos de prova que conduzem à reclamada paternidade. Na ausência de qualquer prova acerca da paternidade, inviável a fixação de alimentos provisórios. Agravo de instrumento desprovido (TRIBUNAL DE JUSTIÇA DO RIO GRANDE DO SUL. Agravo de Instrumento AI 70074250002 RS. Sétima Câmara Cível, Tribunal de Justiça do RS. Relator: Jorge Luís Dall'Agnol. Julgado em 24/10/2017. Sétima Câmara Cível, Tribunal de Justiça do Rio Grande do Sul, 2017.)

Encontrado em: Sétima Câmara Cível Diário da Justiça do dia 26/10/2017 26/10/2017 Agravo de Instrumento Al 70074250002 RS (TRJ-RS). Jorge Luís Dall'Agnol.

E quanto à concessão dos alimentos gravídicos, isto na medida em que não haja possibilidade de questionar a presença de boa dose de subjetivismo ao juiz, o que para tanto se tendo de considerar dificuldades buscando meios que pelos mesmos se prove a paternidade, apresentando provas diante 
do magistrado. E isto, de uma forma tal que apesar de o réu confirmar, na maioria das vezes, que manteve relação sexual poucas vezes com a gestante segundo Beraldo (2017).

\section{TJ-RS - Agravo de Instrumento Al 70080187107 RS (TJ-RS) Data de Publicação: $18 / 12 / 2018$}

Ementa: AÇÃO DE ALIMENTOS GRAVÍDICOS. AUSÊNCIA DE ELEMENTOS DE CONVICÇÃO SEGUROS A ATESTAR A ALEGADA

PATERNIDADE. No caso, a agravante, alegando que manteve relacionamento amoroso com recorrido, mas os elementos constantes nos autos são insuficientes para a fixação de alimentos gravídicos, nos termos do art. 6 da Lei no 11.804/2008, com o que a manutenção da decisão agravada é medida que se impõe. RECURSO DESPROVIDO (TRIBUNAL DE JUSTIÇA DO RIO GRANDE DO SUL. Agravo de Instrumento № 70080187107. Sétima Câmara Cível, Tribunal de Justiça do Rio Grande do Sul. Relatora: Liselena Schifino Robles Ribeiro. Julgado em 17/12/2018)

Encontrado em: Sétima Câmara Cível Diário da Justiça do dia 18/12/2018 18/12/2018 Agravo de Instrumento Al 70080187107 RS (TRJ-RS). Liselena Schifino Robles Ribeiro.

O Tribunal de Justiça, em algumas decisões, tem mostrado de modo que agindo pela reformulação de decisões que fixam alimentos gravídicos, em favor da autora da ação impetrada, diante da inexistência de provas sequer indiciárias de ser o réu o pai. Em contrapartida, há possibilidade de verificar a fixação dos alimentos gravídicos, liminarmente, no que se diz respeito a outros demais casos.

O dispositivo, previsto na Constituição Federal de 1988, Art. 1ㅇ, inciso III, garante ao réu um julgamento de modo justa em relação à dignidade da pessoa humana (BRASIL, 2015).

Na busca pela incontestabilidade da obrigação alimentar, doutrina e jurisprudência entendem que o dever de prestar alimentos detém de um caráter que tanto complementar como subsidiário em decorrência de divisibilidade da sua essência. Dessa forma, os alimentos gravídicos representam uma verdadeira indenização pertinente à mãe, no que condiz um sentido para com as despesas específicas da gravidez.

Assim, ainda que caiba afirmar, que a efetivação do caso no que concerne à condenação do devedor de alimentos gravídicos, quando somente fundamentado por meio de indícios de paternidade, estará determinando uma afronta ao direito de um suposto pai de ser condenado apenas após o trânsito em análise. E isto de modo a preservar a garantia dada pelo princípio da dignidade da pessoa humana.

Desta maneira se pode dizer ser inevitável uma ressalva ainda que em função da natureza jurídica eminentemente alimentar, isto é, da indenização dos alimentos gravídicos, sem afrontar o domínio do 
art. 5으, inciso LXVII, da Constituição Federal de 1988, uma vez que a vida do nascituro é o bem maior a ser protegido durante toda a gravidez culminando com o nascimento da criança.

AGRAVO DE INSTRUMENTO. AÇÃO DE ALIMENTOS GRAVÍDICOS. POSSIBILIDADE, NO CASO. REDUÇÃO DA VERBA ALIMENTAR.

DESCABIMENTO. 1. O requisito exigido para a concessão dos alimentos gravídicos, qual seja, "indícios de paternidade", nos termos do art. 6으 da Lei no 11.804/08, deve ser examinado, em sede de cognição sumária, sem muito rigorismo, tendo em vista a dificuldade na comprovação do alegado vínculo de parentesco já no momento do ajuizamento sob pena de não se atender à finalidade da lei, que é proporcionar ao nascituro seu sadio desenvolvimento. 2. No caso, considerando os documentos comprobatórios da gestação, as fotografias e as mensagens trocadas pelas partes em rede social são bastantes a indicar que mantiveram relacionamento amoroso, confortando suficientemente a versão de que ocorreu em período próximo da concepção, restando autorizado o deferimento dos alimentos gravídicos, em $30 \%$ do salário mínimo, patamar que não representa qualquer sorte de demasia, devendo ser mantido. 3. Além disso, após o nascimento com vida, os alimentos gravídicos ficam convertidos automaticamente em pensão alimentícia em favor do menor até que uma das partes solicite a sua revisão, conforme dispõe o parágrafo unido do art. 6 o da Lei no 11.804/08, não havendo que se falar em perda do objeto. Agravo de instrumento desprovido. (TRIBUNAL DE JUSTIÇA DO RIO GRANDE DO SUL. Agravo de Instrumento 70071768782 Al. Oitava Câmara Cível, Tribunal de Justiça do Rio Grande do Sul, Relator: Ricardo Moreira Lins Pastl, Julgado em 09/03/2017)

Encontrado em: Oitava Câmara Cível Diário da Justiça do dia 09/03/2017 09/03/2017 AGRAVO DE INSTRUMENTO. AÇÃO DE ALIMENTOS GRAVÍDICOS. POSSIBILIDADE, NO CASO. REDUÇÃO DA VERBA

ALIMENTAR. Al 70071768782. Relator: Ricardo Moreira Lins Pastl, Julgado em 09/03/2017.

Diante do exposto, eis a questão no que haja também de se considerar como pauta a ser colocada em discussão é se tal norma, desta maneira, está a violar o princípio da presunção de inocência do suposto pai. Fato que como então postado, uma vez que o mesmo poderá ser condenado a pagar alimentos à gestante, existindo possibilidade da conversão desses alimentos em pensão alimentícia, após o nascimento da criança.

A vida do nascituro, desta maneira, enquanto bem este ainda que deva ser preservado em detrimento de uma possível condenação do suposto pai, à perda da liberdade, condigna diante do que diz respeito a não reparação dos alimentos da mulher gestante.

Uma disciplina no tocante à providência como aqui então focada, e que, portanto, à determinação do direito aos alimentos gravídicos, referindo-se à atribuição de parte das despesas que deverá ser subsidiada pelo futuro pai da criança durante o período gestacional, convencido o juiz, da existência de indícios da paternidade em questão. Equívocos podendo ser considerados, com a possibilidade de 
averiguar a caracterização, em caso concreto, no que diz respeito aos indícios específicos de paternidade, conforme o art. 1.597, incisos I e II, do Código Civil (BRASIL, 2002). E uma alusão, assim, fazendo-se a um assunto muito polêmico nos dias atuais e que vem sendo bastante explorado no âmbito jurídico, em função de sua disposição como um tema que está a provocar grandes impactos na ordem jurídica e em uma divergência entre os estudiosos da área e órgãos do judiciário.

Situação, que como tal, estando por merecer uma maior concentração, uma vez que a prática tem mostrado uma série de abusos por parte das autoras das ações promovidas no tocante a uma relação para com a questão de alimentos gravídicos como então mencionadas, com a condescendência de alguns magistrados. Estes que tem se posicionado de modo a determinar ao suposto pai, logo após a condenação, o pagamento de pensão alimentícia, em certos casos, liminarmente falando, sem que haja qualquer indício de paternidade.

Ainda havendo de considerar a previsão de que a gestante tem o direito de buscar alimentos no decorrer da gravidez, baseando-se apenas na existência de indícios de paternidade, com a viabilidade de perceber uma atenção especial voltada para proteção aos sujeitos dignos à obtenção de tal subsídio (BRASIL, 2008).

Á respeito dos alimentos gravídicos, ainda que também podendo ser interpretados de uma maneira que se podendo considerar a seguinte afirmação:

Os alimentos gravídicos são os alimentos recebidos pela gestante no período de gestação para que sejam supridas todas as necessidades do nascituro até a completude do seu desenvolvimento para que estes sejam transformados em alimentos previstos no Código Civil, alimentos cujos pais são obrigados a prestar aos seus filhos para fins de subsistência dos mesmos. (CACHAPUZ; BITTENCOURT, 2009, p. 3)

Alimentos aqui, pois, referidos em sentido amplo, uma vez que abrangem os valores necessários para cobrir as despesas adicionais de todo o período de gravidez, da concepção ao parto, inclusive, aquelas despesas, que se referem à alimentação especial, assistência médica e psicológica.

Por fim, saliente-se ser imprescindível a tese de que em caso de conchavo de princípios, de um lado, a presunção da inocência, e de outro, a dignidade da pessoa humana, pela proteção do nascituro e pelo direito aos alimentos, quando da observância pelo bem maior de cada ser humano, que é a vida. Pelo averiguado aqui, diante das considerações abordadas, já existe possibilidade de se entender a questão de que não deve haver afrontamento à presunção de inocência, conforme a temática aqui abordada. 


\section{OS ALIMENTOS GRAVÍDICOS FRENTE AO PRINCÍPIO DA PRESUNÇÃO DE INOCÊNCIA}

"Generosa ambição é aquela de quem pretende melhorar o seu estado sem prejuízo de terceiros"

\section{(Miguel Cervantes)}

Diante do propósito em apresentar uma análise á respeito da relação entre a concessão de alimentos gravídicos e o princípio da presunção da inocência, isto dentre a uma conexão com fatos em meio a uma menção tanto a aspectos que possam fazer com que se aplique uma sentença, que não erroneamente efetuada.

Sobre princípio da presunção de inocência, ainda que, portanto, sob a determinação de que seja um dos princípios fundamentais no âmbito do Direito hoje aplicado no país, e ainda que se revelando como agente na defesa pela liberdade do de cada indivíduo (SOUZA, 2011).

Pelo exposto acima, algo que se deva ter em mente, dentre outras questões, a razão no que implica um sentido para com o princípio da presunção de inocência quando de uma alusão à Constituição Federal, art. 5ำ, inciso LVII que designa o seguinte: "ninguém será considerado culpado até o trânsito em julgado de sentença penal condenatória." (BRASIL, 2015, p. 13).

Algo uma vez que sob a intenção de apreciar a lei em destaque de forma estritamente falando, vejase a legislação infraconstitucional enquanto setor dentro da esfera jurisdicional que tenha de se prontificar a absorver e cumprir o estipulado pelo mencionado princípio (SOUZA, 2011).

Toda uma perspicácia, esta sob a presença de indícios de paternidade, o que deve ser questionado dentre outros pontos para que assim, enquanto exigência estabelecida, a fim de dá cumprimento de fato para com a aprovação da concessão de alimentos gravídicos (SILVA, 2013).

E por este feito eis que também se veio por considerar o posicionamento de França (2004, p. 307), com o esclarecimento de que: "a presunção só pode ser considerada dentro de um conjunto de indícios e desde que esses elementos sejam criteriosamente avaliados.".

Algo quando vale fazer uma ressalva ao princípio da presunção de inocência de forma a compreender que a concessão dos alimentos gravídicos ocorrendo por meio de simples indícios de paternidade, infringe fervorosamente o preceito como aqui em foco (PIMENTA, 2009).

Um entendimento no que vale ponderar de modo que levando em conta uma posição da justiça brasileira, e isto quando de representação conforme o Agravo de Instrumento como logo a seguir retratado: 
AGRAVO DE INSTRUMENTO. AÇÃO DE ALIMENTOS GRAVÍDICOS. LEI № 11.848/08. AUSÊNCIA DE INDÍCIOS DA PATERNIDADE. O deferimento de alimentos gravídicos à gestante pressupõe a demonstração de fundados indícios da paternidade atribuída ao demandado, não bastando a mera imputação da paternidade. Exegese do art. 60 da Lei 11.848/08. Ônus da mulher diante da impossibilidade de se exigir prova negativa por parte do indigitado pai. Ausente comprovação mínima das alegações iniciais, resta inviabilizada, na fase, a concessão dos alimentos reclamados, sem prejuízo de decisão em contrário diante de provas nos autos. (TRIBUNAL DE JUSTIÇA DO RIO GRANDE DO SUL. Agravo de Instrumento AI Desprovido № 70028646594. Sétima Câmara Cível, Tribunal de Justiça do RS, Relator: André Luiz Planella Villarinho. Julgado em 15/04/2009. Sétima Câmara Cível, Tribunal de Justiça do Rio Grande do Sul, 2009.)

Deste modo, demasiadamente em oposição ao não atendimento à concessão de alimentos gravídicos como de fato deva ocorrer, segundo foi possível constatar através da Súmula no 7/STJ, como prontamente expresso:

1. Embargos de declaração recebidos como agravo regimental em face do nítido caráter infringente das razões recursais Aplicação dos princípios da fungibilidade recursal e da economia processual. 2. Não ocorre omissão quando as questões submetidas ao Tribunal de origem são enfrentadas fundamentadamente. 3. No caso, tem-se que o eg. Tribunal de origem julgou procedente o pedido de investigação de paternidade considerando todo o contexto fático-probatório dos autos, e não apenas o fato de o ora recorrente ter se esquivado da realização do exame de DNA por duas vezes, sem qualquer justificativa plausível, o que gera presunção relativa. Desse modo, a inversão do julgado encontra óbice no enunciado no 7/STJ.

EMBARGOS DE DECLARAÇÃO RECEBIDOS COMO AGRAVO REGIMENTAL. AGRAVO DE INSTRUMENTO. VIOLAÇÃO AO ARTIGO 535 DO CÓDIGO DE PROCESSO CIVIL. INEXISTÊNCIA. INVESTIGAÇÃO DE PATERNIDADE. EXAME DE DNA. RECUSA IMOTIVADA. REEXAME DE PROVAS. SÚMULA № 7/STJ.

4. Agravo regimental a que se nega provimento. (SUPERIOR TRIBUNAL DE JUSTIÇA. Embargos de Declaração no Agravo de Instrumento n. 1.168.320-MG. Superior Tribunal de Justiça. Relator Ministro Raul Araújo. Data do Julgamento: 08 de fevereiro de 2011. Superior Tribunal de Justiça, 2011)

Todavia, é possível concluir que no transcorrer da ação de averiguação acerca da paternidade eis o entendimento de que segundo a Lei 12.004, de 29 de julho de 2009, Art. 2o, Art. 2o-A, Parágrafo único com então abaixo colocado:

Art. 2o-A. Na ação de investigação de paternidade, todos os meios legais, bem como os moralmente legítimos, serão hábeis para provar a verdade dos fatos.

Parágrafo único. A recusa do réu em se submeter ao exame de código genético - DNA gerará a presunção da paternidade, a ser apreciada em conjunto com o contexto probatório. (BRASIL, 2009) 
E assim, é viável fazer uma alusão à Súmula n. 301 do Superior Tribunal de Justiça, esta garantindo que: "em ação investigatória, a recusa do suposto pai a submeter-se ao exame de DNA induz presunção juris tantum de paternidade".

Desta maneira, existe conhecimento de que com a aplicação do princípio da presunção de inocência haja viabilidade de constatar a garantia processual imputada ao réu no que se refere prática de infração penal, ofertando-lhe o benefício de não ser considerado responsável por um ato delituoso até que a sentença penal condenatória siga em análise (FERRARI, 2012).

Assim, para que ocorra a observância do princípio como anteriormente também posicionado, sem, contudo, de forma que com a supressão das grandes conquistas das mulheres, necessário se faça realizar uma análise profunda dos impactos que a aplicação da lei como aqui referenciada possa causar. Repercussões tais no que se refere um sentido para com as partes envolvidas no processo e toda sociedade na vertente das disciplinas doutrinárias apontadas.

Efeitos como no caso referente à questão da paternidade responsável e a influência da concessão dos alimentos gravídicos visando-se intervir pela questão no que corresponde à: "proteção da vida intrauterina, e ao mesmo tempo, convoca os pais a possuírem uma postura coerente com os seus deveres enquanto provedores da vida que brota no ventre materno. " (SIMÕES; FERMENTÃO, 2011, p.2)

E isto ainda que em meio a uma conscientização quanto aos deveres atribuído à paternidade para com a criança que está sendo gerada, sob a ação proposta para mãe junto à justiça brasileira de um modo tal que dentro de uma lógica, para que assim, a justiça se pronuncie coerentemente.

\section{O PRINCÍPIO DA PRESUNÇÃO DE INOCÊNCIA}

"A destreza pode muito, mas, mais a perseverança"

\section{(Adágio popular)}

No que concerne ao Princípio da Presunção de Inocência, por ora é importante o entendimento sobre o significado deste, no âmbito das garantias fundamentais, quanto ao cerceamento da liberdade do suposto pai, como sendo, de um lado, a luta pela liberdade individual, ou seja, a briga entre o Estado e o afrontamento ao indivíduo, em detrimento da própria afirmação do Estado em favor do futuro cidadão: o nascituro, visando a garantia dos direitos deste, sobretudo a dignidade da pessoa humana. Num primeiro momento, pode-se observar que a presunção de inocência vem da carência de uma garantia da dignidade da pessoa humana. 
A dignidade da pessoa humana, predominantemente jurídica, ao passo que a presunção de inocência vem da limitação do Poder Público, face ao arbítrio do Estado.

Entenda-se, que o Princípio da Presunção de Inocência, previsto de forma explícita (CF/1988, art. 5으, inciso (VII), bem como o Princípio da Dignidade da Pessoa Humana, tratam-se verdades que necessariamente devem ser observadas em todo e qualquer lugar, em qualquer ocasião, e em todas as circunstâncias, para que se concretize a vida do "Ser", na forma efetivamente "humana", como cidadão em uma sociedade livre, justa e solidária.

Dessa forma, todo e qualquer fator que implique em restringir a liberdade de alguém, deve ser afastado, por ferir a Constituição Federal e o Estado de Democrático de Direito.

Como ensina Alexandre de Morais, citado por Cocuruto (2008, p. 46): "Sem respeito à dignidade da pessoa humana não haverá Estado Democrático de Direito [...]."

O princípio da proporcionalidade serve como instrumento de interpretação quando houver antagonismo entre direitos fundamentais, ou situação de colisão de princípios constitucionais.

Assim, o enfoque da hermenêutica constitucional, diante de eventual situação de colisão de princípios, vale destacar a possibilidade de aplicação do princípio da proporcionalidade, que em sua incidência exige a presença de três requisitos, a saber: "proporcionalidade em sentido estrito, adequação e exigibilidade".

A proporcionalidade em sentido estrito considera o fim que pode ser atingido por diversos meios, o qual deverá ser essencial, menos gravoso e atingir o máximo de vantagens como desrespeito aos demais valores também protegidos.

O meio a ser escolhido deverá ser adequado para o resultado pretendido, portanto útil ao fim desejado.

Por fim, a exigibilidade considera o máximo de vantagens dentre os valores meios possíveis, logo, o mais suave ou menos agressivo e menos gravoso.

É no direito de família que mais se sente o reflexo dos princípios consagrados pela Constituição Federal de 1988, consagrados como princípios fundamentais, com o enfoque atribuído aos valores sociais dominantes. 
No conceito atual da família, tem como prioridade dar suporte emocional ao indivíduo, modelo fundado na responsabilidade da afetividade, tem seu ponto de apoio no individuo, e não mais nos bens ou coisas que guarneciam a relação familiar.

O artigo 40 da Convenção Americana de Direitos Humanos impõe que a lei deve proteger a vida e proteger a vida e proclama que esse direito tem início com a concepção, corroborando entendimento da jurisprudência do Supremo Tribunal Federal, ao afirmar que: "os tratados internacionais de direitos humanos subscritos pelo Brasil possuem status normativo supralegal, o que torna infraconstitucional com eles conflitantes, seja ela anterior ou posterior ao ato de ratificação.

O princípio da dignidade humana, insculpido no artigo 10, III, da Constituição Federal de 1988, "fundante do Estado Democrático de Direito", enaltece a preocupação do Constituinte com a promoção dos direitos humanos e justiça social, como bem leciona Alexandre de Moraes, para quem o direito à vida e à saúde, entre outros, aparece como consequência imediata da dignidade da pessoa como fundamento da República Federativa do Brasil.

Considerando princípio da dignidade da pessoa como princípio fundamental do Estado Democrático de Direito, por ser o núcleo de uma estrutura organizada, deverá sempre preponderar em caos de colisão de princípios.

Por fim, conforme acentua Cocuruto (2008, p. 50): "o fim almejado em situação de rota de colisão na incidência simultânea de dois ou mais princípios deverá ser sempre a dignidade da pessoa humana."

Nessa linha de pensamento escreve Nunes (2002, p. 54):

É verdade que o chamado princípio da proporcionalidade, que serve de instrumento para a resolução do eventual conflito entre princípios constitucionais, para a doutrina, está ligado ao princípio da igualdade, mas, como o demonstraremos, não só o mais importante elemento principiológico constitucional é o da dignidade da pessoa humana, conforme já adiantamos, o princípio da proporcionalidade deve ser tido como originário desse outro da dignidade".

É oportuno frisar, que os princípios delineados no presente estudo, o princípio da dignidade da pessoa humana dá a direção para a solução. Por sua vez, Willis Santiago afirma: “[...] enunciados no artigo 10 da Constituição Federal de 1988, merece destaque especial aquele que impõe o respeito à dignidade da pessoa humana". 
Segundo Canotilho (2000, p. 256) “O homem necessita de segurança para conduzir, planificar autônoma e responsavelmente a sua vida". O ilustre doutrinador, afirma que: "[...] desde cedo se considera o princípio da segurança jurídica como elemento constitutivo do Estado de Direito."

É por demais, necessário afirmar, que em todos os ramos jurídicos, especialmente com o Direito de família, é fundamental que o Estado, através do Poder Judiciário, proporcione segurança aos seus cidadãos, através das suas decisões prolatadas: neste particular a segurança jurídica.

O princípio da segurança jurídica, insculpido no artigo 5o, inciso XXXVI, da Constituição Federal de 1988, enaltece a importância da pessoa como sujeito de direito, considerando pessoa, “[...] nesta perspectiva, o valor supremo da democracia, que dimensiona a humaniza".

O aludido princípio é de capital importância na Seara do Direito, principalmente nos tempos de hoje, no presente contexto social pátrio, uma vez que: “a lei não prejudicará o direito adquirido, o ato jurídico perfeito e a coisa julgada"; Posto que, assim dispõe o Código de Processo civil de 2015, em seu artigo 502, in verbis: "Denomina-se coisa julgada material a autoridade que torna imutável e indiscutível a decisão de mérito não mais sujeita a recurso."

Para Silva (1994, p. 110), “A tarefa fundamental do Estado de Direito consiste em superar as desigualdades e instaurar em regime democrático que realize a justiça social."

Assim, conforme demonstrado no capitulo em tela, diante de previsão estatuída na Lei no 11.804/2008, é medida legal a concessão de alimentos à mulher gestante, tratando-se de norma especial, respeitando previsão da Constituição Federal de 1988, no artigo 19, inciso III, quanto a vedação à distinção entre brasileiros.

Art. 19. É vedado à União, aos Estados, ao Distrito Federal e aos Municípios:

$[\ldots]$

III - criar distinções entre brasileiros ou preferências entre si.

Ainda a respeito da presunção de inocência, consoante inestimável ensinamento de Moro (2005), ao afirmar que:

O fundamento principal daqueles que exigem um julgamento definitivo para a execução de uma condenação criminal é o antigo e basilar princípio da presunção de inocência, que, em nossa Constituição, foi contemplado no artigo 5ㅇ, LVII. Tal norma constitucional comporta, porém, várias intepretações.

Por certo, no Direito de família, assim como em outros ramos do Direito, é fundamental a manutenção das decisões, enaltecendo o princípio da "Segurança jurídica", a fim de que os direitos decorrentes dessas relações não ensejem em meio ilícito de enriquecimento. 
É bastante controverso a questão da concessão dos alimentos gravídicos, pois requer a presença do Estado, conforme Cahali $(2012$, p. 16) se posicionando de modo a poder considerar o entendimento de que: "Constituem os alimentos uma modalidade de assistência imposta por lei, de ministrar os recursos necessários à subsistência, à conservação da vida, tanto física como moral e social do indivíduo".

\section{METODOLOGIA}

"O camaleão reveste-se de todas as cores, exceto o branco: o adulador a tudo arremeda, exceto a verdade"

\section{(Plutarco)}

Para a realização da produção científica aqui apresentada se fez uso do método de pesquisa sócio jurídico. Algo uma vez que se buscou obter conhecimentos sobre as incoerências do sistema jurídico no que tange aos alimentos gravídicos outorgados em benefício da gestante, pelo suposto pai, e isto ainda que diante do possível afrontamento ao princípio da presunção de inocência.

O tema veio por ser abordado de um modo tal onde se promoveu um estudo com base em uma determinada circunstância posto um sentido em meio à viabilidade de poder identificar e apresentar os pontos críticos em torno da aplicação que, portanto, de uma percepção acerca do que diz respeito: aos alimentos gravídicos conforme o princípio da presunção de inocência. E isto ao levar em conta a realidade vivenciada por cada cidadão brasileiro e o direito previsto na legislação respectivamente falando, ao se fazer uma referência tanto à jurisprudência como às doutrinas peculiares à ciência jurídica.

Para tanto, foi adotada a pesquisa bibliográfica fazendo uso de meios que como tais, de acordo com o posicionamento de Fonseca (2002, p. 32), concebidos:

A partir do levantamento de referências teóricas já analisadas, e publicadas por meios escritos e eletrônicos, como livros, artigos científicos, páginas de web sites. Qualquer trabalho científico inicia-se com uma pesquisa bibliográfica, que permite ao pesquisador conhecer o que já se estudou sobre o assunto. Existem, porém, pesquisas científicas que se baseiam unicamente na pesquisa bibliográfica, procurando referências teóricas publicadas com o objetivo de recolher informações ou conhecimentos prévios sobre o problema a respeito do qual se procura a resposta.

Todo um contexto quando do trato para com um aspecto metodológico tendo-se utilizado como norteio uma concepção onde se colocou em pauta, dentre outros pontos, objetivos e à forma de 
abordagem, a fim de melhor contextualizar sobre um objeto de estudo que se supõe ser relevante para a sociedade e para a jurisdição aqui tratada.

\section{CONSIDERAÇÕES FINAIS}

O trabalho aqui apresentado acredita-se ter atendido aos objetivos propostos, e outros requisitos a mais diante da abordagem como no presente instante aqui apresentada.

Objetivos que como então aplicados, o que se propôs levar em conta, de modo geral, e assim elaborado o objetivo identificado da seguinte maneira: Identificar dados sobre a aplicação da legislação e da jurisprudência vigentes diante de uma referência a possíveis efeitos da concessão de alimentos à gestante, confrontando com o princípio constitucional da presunção de inocência.

E quanto aos objetivos específicos:

- Selecionar todo um contexto sob um direcionamento a respeito da concessão de alimentos e a situação desta em consonância com termos voltados para o processo de tal ação, ao ter em mente um entendimento conforme a estruturação da família e a conjuntura legal em relação a aspectos relacionados à mesma;

- Interpretar sobre o arcabouço histórico da família e a concessão dos alimentos perante a sociedade e a legislação em torno de tal questão, na medida em que exista por se fazer uma referência a termos conforme encadeamento de ideias diante, que, portanto, da temática aqui retratada.;

- Redigir a respeito de aspectos inerentes à concessão dos alimentos em meio a circunstâncias no que tange aspectos vinculados ao termo gravídico e ao que remete uma relação para com termos jurídicos como também constitucionais em conformidade com a legislação e a jurisprudência em vigor.; e,

- Apresentar uma abordagem em relação à concessão dos alimentos com um entendimento em concomitância ao princípio da presunção de inocência, dentre outros aspectos norteadores, contudo um sentido maior eis que para tal princípio, como também para particularidades próprias da conjuntura da família, enquanto aspectos propícios à prerrogativa sobre a concessão abordada. 
Uma produção de cunho científico assim como ainda que também que dentre a uma referência ao tema abordado: “Os Alimentos Gravídicos Frente ao Princípio da Presunção de Inocência”, sabe-se de ter sido interessante promover uma análise diante do que existiu de se levar em conta uma desenvoltura acerca de questões imprescindíveis de serem mencionadas. Circunstâncias que se diga como no tocante aos efeitos de aspectos constitucionais como também jurídicos, em meio que tanto à Constituição Federal de 1988 como ao Direito de Família e demais pontos.

$E$ isto ainda que enquanto fatos referentes a um tema que muito fez por contribuir com uma compreensão eficaz à desenvoltura no contexto da jurisdição brasileira. 


\section{REFERÊNCIAS}

BARROSO, L. R. Interpretação e aplicação da Constituição. 2a ed. São Paulo: Saraiva, 1998.

BARROSO, L. R.; BARCELLOS, A. P. de. o Começo da História. A Nova Interpretação Constitucional e o Papel dos Princípios no Direito Brasileiro. Revista de Direito Administrativo, n. 232, p. 141-176, Rio de Janeiro, abr./jun., 2003.

BERALDO, L. de F. Alimentos no Código Civil: aspectos atuais e convertidos com enfoque na jurisprudência. 2a ed. rev., atual. e ampl. Belo Horizonte: Fórum, 2017.

BRASIL. Câmara dos Deputados. Constituição da República Federativa do Brasil. Texto constitucional promulgado em 5 de outubro de 1988, com as alterações adotadas pelas Emendas constitucionais nos 1/1992 a 90/2015, pelo Decreto legislativo no 186/2008 e pelas Emendas constitucionais de revisão nos 1 a 6/1994. 48. ed. Brasília - DF: Câmara dos Deputados, Edições Câmara, 2015.

. Presidência da República. Casa Civil. Subchefia para Assuntos Jurídicos. Código Civil. Lei no 10.406, de 10 de janeiro de 2002. Brasília - DF: Presidência da República, 2002.

. Presidência da República. Casa Civil. Subchefia para Assuntos Jurídicos. Lei 12.004, de 29 de julho de 2009. Altera a Lei no 8.560, de 29 de dezembro de 1992, que regula a investigação de paternidade dos filhos havidos fora do casamento e dá outras providências, Brasília - DF: Presidência da República, 2009.

- Presidência da República. Casa Civil. Subchefia para Assuntos Jurídicos. Lei no 11.804, de 5 de novembro de 2008. Disciplina o direito a alimentos gravídicos e a forma como ele será exercido e dá outras providências. Brasília - DF: Presidência da República, 2008.

CACHAPUZ, R. da R.; BITTENCOURT, B. da R. Alimentos gravídicos: o direito real desde a concepção. Âmbito Jurídico, XII, n. 64, Rio Grande, maio, 2009.

CAHALI, Y. S. Dos alimentos. 7ạ ed. rev. e atual. São Paulo: Editora Revista dos Tribunais, 2012.

CANOTILHO, J. J. G. Direito Constitucional e Teoria da Constituição. Coimbra: Almedina, 2000.

COCURUTTO, A. Os Princípios da Dignidade da Pessoa Humana e da Inclusão Social. 1ạ ed. São Paulo: Malheiros, 2008.

DIAS, M. B. Alimentos: direito, ação, eficácia e execução. 2ª ed. rev., atual. e ampl. São Paulo: Editora Revista dos Tribunais, 2017.

. Manual de direito das famílias. 10ạ ed. rev., atual. e ampl. São Paulo - SP: Editora Revista dos Tribunais, 2015.

. Manual de Direito das Famílias. 12. ed. rev., atual. e ampl. São Paulo: Editora Revista dos Tribunais, 2017.

. Manual de Direito de Família. 8a ed. rev. e atual. São Paulo: Editora Revista dos Tribunais, 2011.

. Manual do Direito das Famílias. 5a ed. rev., atual. e ampl. Editora Revista dos Tribunais, 2009. 
FACHIN, Z.; SPÍNDOLA, F. D.; TAUIL, I. M. de O. O nome como direito personalíssimo e uma expressão do princípio constitucional da Dignidade Humana. São Paulo: Método, 2008.

FARIAS, C. C.; ROSENVALD, N. Direito civil: teoria geral. 7ạ ed. Rio de Janeiro: Lumem Juris, 2008.

FARIAS, C. C. de. Redesenhando os contornos da dissolução do casamento. Artigo de Revista, 2007.

FERRARI, R. O princípio da presunção de inocência como garantia processual penal. Revista Jus Navigandi, ano 17, n. 3249, Teresina, 24 maio 2012.

FERST, M. da C. Alimentos \& ação de alimentos - Manual do operador do Direito. 2a ed. rev. e atual. Curitiba: Juruá, 2013.

FIÚZA, C. Direito Civil - Curso Completo. 12. ed. Belo Horizonte: Editora Del Rey, 2008.

FONSECA, J. J. S. Metodologia da Pesquisa Científica. Fortaleza: UEC, 2002.

FRANÇA, G. V. de. Medicina Legal. 7ạ ed. Rio de Janeiro: Guanabara Koogan, 2004.

FREITAS, D. P. Alimentos Gravídicos e a Lei 11.804/2008. Revista IOB de Direito de Família, v. 9, no 51, Porto Alegre: Síntese, jan./fev. 2009.

GAMA, G. C. N. da. O Companheirismo. 1998; Editora: Revista dos Tribunais, 1998.

HIRONAKA, G. M. F. N. Família e casamento em evolução. Revista Brasileira de Direito de Família, Porto Alegre, 1999.

LIMA, G. M. As funções dos princípios constitucionais. Âmbito Jurídico, III, no 8, Rio Grande, fev., 2002.

MARTINS, I. G. da S. (Coord.). Pesquisas Tributárias - Nova Série. n. 11. São Paulo: Editora Revista dos Tribunais, 2005.

MIRANDA, P. de. Tratado de Direito Privado. Campinas: Bookseller, 2000. (Tomo VIII)

MORO, S. F. Observatório Jurídico - Justiça criminal em risco. Revista Consulex, Ano IX, no 206, Matéria de Capa, 2005.

NUNES, R. Princípio Constitucional da Dignidade da Pessoa Humana. São Paulo: Saraiva, 2002.

ORO, M. L. Lei no 11.804/08 - Do direito aos alimentos gravídicos: aspectos materiais e processuais. 2011.

PENARIOL, E. L. A importância da aplicação do instituto da segurança jurídica, no âmbito do Direito Processual Civil brasileiro, frente as frequentes alterações legislativas. Âmbito Jurídico, XV, n. 104, Rio Grande, set., 2012.

PEREIRA, R. da C. Princípios fundamentais norteadores do Direito de Família. 5a ed. v. 1. Belo Horizonte: Del Rey, 2005.

PERROT, M. O nó e o ninho. In: Reflexões para o futuro. São Paulo, abril, 1993. 
PIMENTA, N. C. M. A importância social da lei dos alimentos gravídicos. jusvi.com, 2009. [on-line]

RAMOS, E. da S. Ativismo Judicial: Parâmetros dogmáticos. São Paulo: Saraiva, 2010.

SANTOS, A. A. dos. O Estado Democrático de Direito. Âmbito Jurídico, XIV, n. 91, Rio Grande, ago., 2011.

SILVA, D. C. Alimentos gravídicos: o titular desse direito e a presunção juris tantum de paternidade. Âmbito Jurídico, XVI, n. 110, Rio Grande, mar., 2013.

SILVA, J. J. G. Direito Constitucional e Teoria da Constituição. 5ạ ed. Coimbra: Almeida, 2002.

SILVA, J. A. da. Curso Direito Constitucional Positivo. São Paulo: Malheiros, 1994.

SIMÕES, F. M.; FERMENTÃO, C. A. G. R. Dos Alimentos Gravídicos e a Dignidade da Pessoa Humana. Tese. Mestrado em Ciências Jurídicas. Maringá: Centro Universitário de Maringá, 2011.

SOUZA JUNIOR, A. B.; MEYER-PFLUG, S. R. O ativismo judicial no Supremo Tribunal Federal. Acesso à justiça II. XXII Encontro Nacional CONPEDI/ UNICURITIBA, 2013, Curitiba. Curitiba: JUNJAB, 2013.

SOUZA, R. S. e. O Princípio da Presunção de Inocência e sua aplicabilidade conforme entendimento do Supremo Tribunal Federal. E-gov - Portal de e-governo, inclusão digital e sociedade do conhecimento, out., 2011.

SUPERIOR TRIBUNAL DE JUSTIÇA. Embargos de Declaração no Agravo de Instrumento n. 1.168.320MG. Superior Tribunal de Justiça. Relator Ministro Raul Araújo.Data do Julgamento: 08 de fevereiro de 2011. Superior TribunaldeJustiça,2011.

TARTUCE, F. Direito Civil: Direito de Família. v. 5. 12. ed. rev., atual. e ampl. Rio de Janeiro: Forense, 2017.

TORRES, R. L. Limitações ao Poder Impositivo e Segurança Jurídica. In: MARTINS, I. G. da S. (Coord.). Pesquisas Tributárias - Nova Série. n. 11. São Paulo: Editora Revista dos Tribunais, 2005.

TRIBUNAL DE JUSTIÇA DO RIO GRANDE DO SUL. Agravo de Instrumento 70047396924 Al. Oitava Câmara Cível, Tribunal de Justiça do Rio Grande do Sul. Relator: Rui Portanova. Julgado em 09/05/2012. Oitava Câmara Cível, Tribunal de Justiça do Rio Grande do Sul, 2012.

Agravo de Instrumento Al 70074250002 RS. Sétima Câmara Cível, Tribunal de Justiça do RS. Relator: Jorge Luís Dall'Agnol. Julgado em 24/10/2017. Sétima Câmara Cível, Tribunal de Justiça do Rio Grande do Sul, 2017.

TRIBUNAL DE JUSTIÇA DO RIO GRANDE DO SUL. Agravo de Instrumento Al Desprovido № 70028646594. Sétima Câmara Cível, Tribunal de Justiça do RS, Relator: André Luiz Planella Villarinho. Julgado em 15/04/2009. Sétima Câmara Cível, Tribunal de Justiça do Rio Grande do Sul, 2009.

. Agravo de Instrumento № 70080187107 RS. Sétima Câmara Cível, Tribunal de Justiça do RS. Relatora: Liselena Schifino Robles Ribeiro. Julgado em 17/12/2018. Sétima Câmara Cível, Tribunal de Justiça do Rio Grande do Sul, 2017. 
. Agravo de Instrumento № 70071768782 RS. Oitava Câmara Cível, Tribunal de Justiça do RS. Relator: Ricardo Moreira Lins Pastl. Julgado em 09/03/2017. Oitava Câmara Cível, Tribunal de Justiça do Rio Grande do Sul, 2017.

Agravo de Instrumento № 70047396924 RS. Oitava Câmara Cível, Tribunal de Justiça do Rio Grande do Sul. Relator: Rui Porta nova. Julgado em 09/05/2012. Oitava Câmara Cível, Tribunal de Justiça do RS, 2012.

VENOSA, S. de S. Direito Civil: Direito Civil de Família. v. 5. 17. ed. São Paulo: Atlas, 2016. . Direito Civil: Direito de Família. 12. ed. São Paulo: Atlas, 2012.

. Direito Civil: Direito de Família. 8ª ed. v. 6. São Paulo: Atlas, 2008. [Coleção Direito Civil]

VENOSA, Silvio de S. Direito Civil: Direito Civil de Família. v. 6. 10. ed. São Paulo: Atlas, 2010. 


\section{NOTAS}

i. Música: Família - Banda:Titãs

ii. "O Estado democrático de direito é um conceito que designa qualquer Estado que se aplica a garantir o respeito das liberdades civis, ou seja, o respeito pelos direitos humanos e pelas garantias fundamentais, através do estabelecimento de uma proteção jurídica." (SANTOS, 2011, p. 1)

iii. "Etimologicamente, nascituro é a palavra decorrida do latim naciturus, significando aquele que precisará nascer, que está por nascer, nesse passo, o nascituro é aquele que já está gerado, mas ainda não nasceu, é aquele que ainda está no corpo da genitora." (FARIAS; ROSENVALD, 2008, p. 200)

iv. A Cidade antiga, p. 23

v. "Os indícios de paternidade e o possível acordo em audiência de conciliação impõe, salvo que o objeto do acordo seja o reconhecimento voluntário da paternidade, a fixação do suposto pai obrigado pelos alimentos gravídicos como pai daquela prole credora de alimentos. Ao nascer, todo o procedimento de investigação de paternidade deverá ocorrer, lembrando que, se houver reconhecimento voluntário, mas, fundado este em vicio de vontade, poderá ser revisitado em ação própria [...]." (FREITAS, 2009, p. 22)

vi. " [...] Todo o homem, com o fim em si mesmo possui um valor intrínseco, isto é a dignidade. $\mathrm{O}$ que tem um preço pode ser substituído por alguma coisa equivalente; o que é superior a todo o preço e portanto, não permite ser substituído por alguma coisa equivalente, o que é superior a todo o preço, e portanto, não permite ser substituído por alguma coisa, tem uma dignidade. Substancialmente a dignidade de um ser racional consiste no fato de que ela não obedece nenhuma lei que não seja instituída por ele mesmo. A moralidade, como condição dessa autonomia legislativa, é, portanto, a condição da dignidade do homem e moralidade e humanidade são as únicas coisas que não tem preço [...]". (ABBAGNANO, 1962, p. 259, apud FACHIN; SPÍNDOLA; TAUIL, 2008, p. 74)

vii. VENOSA. Silvio de Salvo. Direito de família. 10. Ed. São Paulo: Atlas , 2010, v.6. p. 357. 